Environment Conservation Journal 20 (1\&2) 109-114, 2019

ISSN 0972-3099 (Print) 2278-5124 (Online)

Abstracted and Indexed

\title{
A review article on surgical concepts of Acharya Sushruta
}

\author{
Singh M. ${ }^{1}$, Sharma S. ${ }^{2}$, Sharma S. ${ }^{3}$ and Sharma R. ${ }^{4}$
}

Received: 28.06 .2018

Revised: 28.10 .2018

Accepted: 14.02.2019

\begin{abstract}
Surgery is an integral discipline of medical sciences that constitutes direct physical intervention on body tissues. Surgery has its roots in Ayurveda and Sushruta Samhita is the representative treatise of Indian School of Surgery (Shalya Tantra) by Acharya Sushruta. Sushruta is the revered father of anatomy, Indian surgery and designated first plastic surgeon of the world owing to his remarkable contribution. Principles of surgery laid down by Sushruta inhabit authentic basis and applicability in modern times as well.
\end{abstract}

Key words: Shalya Tantra, Surgery, Sushruta Samhita, Surgical Techniques.

\section{Introduction}

Surgery is the branch of medicine that treats diseases, injuries and deformities by manual or operative methods. Ayurveda has two objectivesalleviation of disease and maintenance of the healthy status. To achieve these objectives, a remarkable contribution has been made by Acharya Sushruta in various respects, particularly in the field of surgery. Acharya Sushruta has been designated as the father of anatomy, Indian surgery and plastic surgery. His contribution has laid down the basic principles of modern surgery, as regards the techniques, theories and concepts are concerned.

\section{Wound Management (Vrana Chikitsa)}

Every surgical procedure starts with the creation of a wound and ends up with its healing. An illustrious concept of Shashti upkrama (sixty modalities) of wound management contributed by Acharya Sushruta reveals his knowledge and proficiency that was limited not only to wound healing but to correct the residual cosmetic defects as well ${ }^{4}$. Holistic wound management as advocated by him includes care of both; the wound and the wounded. An elaborated description of etiology, classification, cilinical features, principles of

\section{Author's Address}

1,2\&4 Department of Shalya Tantra, National Institute of Ayurveda, Jaipur, Rajasthan, India.

${ }^{3}$ Department of Shalya Tantra, Rajiv Gandhi Government Ayurvedic College and Hospital, Paprola, Himachal Pradesh, India.

E-mail.: docmanorma@gmail.com management, stages of wound healing,complications, factors influencing wound healing, regimen to be followed etc., available at various places under different contexts, are all time tested. Various types of dressings and dressing schedule as described by him, hold practically good till date. The main aim of this description seems to protect the wound from untoward complications and to assist the natural process of healing.

Basic Surgical Techniques (Shastra Karma)

He has described eight kinds of surgical techniques (Shastra Karma). Excision (Chhedana), incision (Bhedana), scraping (Lekhana), puncturing (Vedhana), probing (Aeshana), extraction (Aaharana), draining (Visravana) and suturing (Sevana) along with description of their indications. All these techniques are exclusive and indispensable for the practice of surgery.

\section{Principles of Suturing (Sevana Karma)}

Four types of suturing techniques have been described viz. continuous sutures (Vellitaka), blanket sutures (Gophanika), sub-cuticular sutures (Tunna-sevani) and interrupted sutures (Rijugranthi). Indications and contra-indications of suturing along with specific complications resulting from improper placement of sutures is explained in Sushruta Samhita. Description of suturing material includes suturing threads from animal and plant origin like hair of horse and organic suture materials like use of ants while suturing intestinal wounds. Three types of suturing needles viz. round 
bodied needle (Vritta Suchi), cutting needle (Tryastra Suchi) and curved needle (Dhanur-vakra Suchi) along with the description of sites indicated; all have been described.

Principles of Bandaging and Dressing (Vrana Bandhana)

In addition to fourteen types of bandaging techniques (Bandhana Karma) according to the site of application, three types of bandaging knots (Yantrana) and dressing material from organic and inorganic sources have been described. Patient as a whole has been taken into consideration. Bandaging methods vary according to the psycho-somatic constitution of the patient (Prakruti), status of body humors (Dosha viz. Vata, Pitta, Kapha), site of wound (Desha) and seasonal variables (Kala and Ritu). He has described the conditions where bandaging should be avoided. Role of diet and life style regimen (Ahara and Vihara) has been emphasized in a separate chapter.

\section{Experimental Surgery (Yogya Vidhi)}

Good knowledge of anatomy (Sharira Rachna Vigyana) is a prerequisite for practice of surgery. Sushruta was the first to evolve the concept of anatomical dissection on dead bodies (Shavachhedana Karma) and the concept of experimental and practical training (Yogya) by making use of experimental modules like dummy, parts of dead bodies and different natural objects; to gain proficiency in operative surgery. 'Practice leads to perfection' is universal principle advocated by him for all the surgeons of all the times.

\section{Division of Surgical Procedure (Trividha Karma)}

Sushruta has proposed the division of surgical procedures into pre-operative (Poorva Karma), main procedure (Pradhana Karma) and post operative (Pashchata Karma) based on sound scientific principles. Outcome of a surgical intervention depends upon standards of care taken in para-operative management. Every single step of management carry prognostic importance.

Para surgical procedures (Anu-shastra Karma) Sushrutra has broadly described a series of parasurgical procedures viz therapeutic burning (Agnikama), application of alkalies (Kshar Karma), therapeutic blood letting (Jalauka Karma) etc. to treat the various pathological conditions. These are minimal invasive procedures with a good number of indications and variable efficacy. In modern times, the utility of these procedures can be well defined only after their standardization related to site, depth, quantity, instrumentation, number of sittings and specific indications etc.

\section{Therapeutic Blood Letting (Raktamokshana} Karma)

It has been described by Acharya Sushruta as the main line of treatment in various diseases. Venepuncture (Sira vyadha) has been rendered as 'half of the therapeutic measures' (Chikitsa-ardha) of discipline of surgery. An elaborated description of different techniques of therapeutic blood letting (Jalauka Avcharana, Sira vyadha, Prachhana Karma) indications, contraindications, disease specific sites and complications is available. Exact mode of action has not been explained anywhere in any of the Ayurvedic treatises but several clinical trials have revealed efficacy in management of wide range of pathologies. Its adoption as a standard treatment modality requires scientific validation of techniques, site, amount of blood withdrawn, indications, contraindications, complications, instrumentation, specification of vein according to modern anatomy, duration of treatment, number of sittings etc.

\section{Arrest of Bleeding (Shonita-Sthapana)}

Sushruta has specifically highlighted the importance of blood in the field of surgery. Blood loss in surgery is inevitable. Characteristic four local measures to manage the haemorrhage have been described as Skandana (cold application), Sandhana (use of astringents), Pachana (use of ashes), and Dahan (thermal cauterization). These all are used extensively to achieve hemostasis is modern surgical practice as well. Ayurvedic formulations with hemostatic (Rakta stambhana) and haematinic (Rakta vardhana) property may provide additional help in managing such conditions. For replenishment of a major blood loss from the body, administration of fresh blood of animals through oral and rectal routes has been advocated in Ayurveda.

\section{Description of Surgical Instruments (Yantra \& Shastra)}

Surgery is an artwork performed by a surgeon with surgical instruments. Fabrication of surgical instruments both for diagnostic and therapeutic purposes is a magnificient contribution by Sushruta. A detailed description of surgical instruments, 101 
types of blunt instruments (yantra) and 20 types of sharp instruments (shastra), their characteristics, uses, technique of holding, storage (Shastra Kosha) along with methods of maintenance of edges etc. are the remarkable contributions.

\section{Surgical Anatomy and Dissection (Sharira Rachna Vigyana \& Shava-chhedana Karma)}

He was the first man who advocated practical anatomical study by dissection and the first person who had documented cadaveric dissection and preservation of dead body. For dissection purposes, the use of brushes made up of bamboo, to have a layer by layer minute study of the structures from superficial to deep, seven layers of skin, muscles, blood vessels, description of bones, joints, and various organ systems of the body etc. verify his deep knowledge of anatomical aspects.

\section{Description of Vital spots of Surgical Importance (Marma)}

$\mathrm{He}$ has described 107 vital spots (Marma) in the body. Marma are said to cover half of the jurisdiction of Shalya Tantra (Discipline of Shalya Tantra). These are anatomical landmarks of surgical importance. During surgical intervention due precautions should be exerted to protect them. Injury to these vital areas can adversely affect the outcomes of surgery and may even lead to death of the patient. Good knowledge of Marma is indespensable for a surgeon.

Burn Injuries and Therapeutic Burn (Dagdha and Agni Karma)

An elaborated description of both accidental and therapeutic burns classification according to source and depth along with the management principles; have been described by Sushruta. Therapeutic burn (Agnikarma) has a wide range of indications in Ayurveda and has been rendered superior to all other parasurgical procedures. From the description of technique, precautions, complications, management, instrumentation etc.; it is evident that Sushruta had a very deep practical knowledge of all these aspects.

\section{Traumatology (Sadyo-Vrana Chikitsa)}

In Sushruta Samhita, total six types of accidental injuries have been described along with the management principles. Accidental injuries to thoraco-abdominal organs (Ashya) have been described. In abdominal injury where omentum (Medovarti) comes out of the wound, management by excision of the same has been described. Though management principles of head injury, chest injury, pelvic injuries as advocated in Sushruta Samhita lack adequacy of description, yet their mention in this treatise reflect that in Indian school of surgery (Shalya Tantra) such cases of advanced trauma management were managed.

Principles of Emergency Management and Prompt Action (Atyayika-Chikitsa)

Principle of prompt action is the universal principle of emergency management. Management of various life endangering conditions like strangulation (Bahu-rajju-latapasha), haemorrhage (Raktasrava) and drawning (Udaka-pooran-udara) etc. has been described in Sushruta Samhita. Total eight chapters of Kalpa Sthana have been devoted to the toxicology (Agad Tantra) to describe classification, routes, complications and treatment of acute and chronic toxicity.

Concept of contagious diseases (Aupsargic Roga) To achieve the desired surgical outcomes, the concept of infection is vital to understand. Adequate prophylactic measures are in routine practice in every surgical care unit these days. Sushruta has enumerated main contagious diseases under Kushtha Nidana (Upsargik Roga) with a brief description of mode of spread as well.

Staging of Diseases and Six Periods of Treatment (Shat Kriya Kala)

Staging of pathology includes estimation of size and extent of lesion along with the involvement of local and distant tissues. Likewise various pathologies are classified into stages like TNM classification of breast cancer; to design a rational treatment protocol, to know about the complications and for prognostication. Six periods of treatment (Shat Kriya Kala) as described by Sushruta carry the importance in staging and management both.

Gastro Intestinal Tract Surgeries (Udara-Roga Shalya Karma)

Description regarding the surgical approach to Chidrodara (intestinal perforation) and Baddhagudodara (intestinal obstruction) is available in Sushruta Samhita. Thus the procedure of laprotomy has been mentioned. The use of black ants for wound closure is specific to note in this particular reference.

\section{Retained Foreign Body (Pranashta Shalya)}

Under the chapter of Pranashta Shalya the exploration and extraction of different types of 
Retained foreign bodies have been described. These methods vary according to site and direction of insertion and carry the relevance in practice till date.

\section{Orthopaedics (Bhagna Nidana \& Chikitsa)}

A broad concept covering all the fundamental aspects of orthopaedics has been described. Six types of dislocations (Sandhi mukta), 12 types of fractures (Kanda Bhagna), malunion, open fractures, the management principles, concept of rehabilitation, factors influencing fracture healing and regimen; all have a relevant basis and applicability in the modern times as well. Etiopathogenesis and line of treatment of Asthividradhi (osteomyelitis) have also been described.

\section{Proctology}

Different treatment modalities for various anorectal diseases viz. medicines (Bheshaja), therapeutic use of alkalies (Kshar karma), therapeutic burning (Agni karma), therapeutic blood letting by use of leech (Jalauka-avcharana Karma) and operative management (Shastra Karma) have been described. In the management of Arsha, the order of treatment of pile mass has been described. Depending upon the type of fistulous tract, different types of incisions have been advised as $\mathrm{T}$ shaped incision (Langalaka), L shaped incision (Ardha-langalaka), circular incision (Sarvatobhadraka), half moon / semicircular incision (Goteerathaka) and serrated incision (Khajoora-patraka) etc. Kshar Sutra management of fistula in ano has been accepted and recommended as a treatment of choice by modern surgeons as well. Aetiology and treatment of Gudbhransha (rectal prolapse) has been given in the chapters of Kshudra Roga Nidana and Chikitsa.

Urology: Anatomies of urinary bladder (Basti) along with formation of urine in the body, surgical approach and precautions during surgery have been described. Eight vital structures (Marma) have been mentioned by Sushruta that should be protected in all the ways during surgery. Perineal lithotomy and postoperative management of the wound, may be the first reference of surgical management of calculus in the history of surgery. A detailed description of retention of urine and dysuria is available in two separate chapters of Uttar Tantra of Sushruta Samhita.

\section{Cosmetology and Plastic Surgery}

Sushruta is the designated father of plastic surgery. Use of pedical flaps to reconstruct the nose - rhinoplasty (Nasa-Sandhana) is his remarkable contribution. Similarly cheileoplasty (Oshtha Sandhana) and Otoplasty (Karna Sandhana) have also received attention in Sushruta Samhita. He has described the classification of mutilated ear lobe defects and techniques of repair. Fifteen different types of Otoplasties have been described by him. A very good concept of correction of residual defects after healing has been mentioned under 60 modalities of management of wound viz. elevating therapy (Utsadana), depressant measures (Avsadana), blackening therapy (Krishanikarma), whitening therapy (Pandukarma), repilation therapy (Roma-sanjanana), depilation therapy (Romaapharana) etc.

Concept of Revision Surgery: To achieve the desired outcomes, sometimes surgical intervention has to be performed in steps specially when corrective surgeries are executed. Revered Acharya Sushruta has advocated the basic concept of revision surgery in the context of rhinoplasty (Nasa Sandhana).

\section{Gynaecological and Obstetric Surgery}

Complications during pregnancy, difficult delivery, and surgical interventions in confounded foetus (Moodagarbha), description of breast abscess (Stanya Vidhradhi); all have been described. Not exactly the caesarean section but laprotomy or uterus section has been indicated to save the life of the foetus in case of death of mother in the course of labour.

ENT \& Ophthalmology: A wide description of diseases pertaining to supraclavicular region (Oodhava-jatrugata Vikara), operative procedures like couching for cataract, various surgeries of ear, nose, throat, buccal cavity and eyes along with procedures related to dentistry all are attributed to Sushruta.

Biological Debridement: There are five methods of wound debridement viz. biological, autolytic, mechanical, enzymatic and surgical. In biological debridement living organism like maggots are used to clean the dead and devitalised tissues from the wound. Acharya Sushruta gave the concept of biological debridement in wounds resulting from large tumours (Kaphaja Arbuda Chikitsa).

Anaesthesia: Sushruta was the pioneer of anaesthesia. Use of strong alcoholic preparations prior to surgery has been quoted to relieve the pain and discomfort of surgery. 


\section{Concept of Sterilization (Nirjantukarna Rakshavidhana) \\ To get rid of disease causing micro-organisma, fumigation of operative area and indoor patient wards by various medicaments has been described by Sushruta. In the context of excision of omentum (Medovarti Chedana), sterilization of surgical instrument on direct flame has also been given.}

\section{Recommendation of Food}

Owing to the resultant complications, the concept of 'Nil per oral' prior to surgical intervention should be strictly followed. The concept of eating prior to procedure (Praka Bhukta) in minor interventions and empty stomach (Abhukta) in major surgery carry scientific basis- to make the patient tolerant for the pain of procedure and to check vomiting and related complications respectively. Furthermore, Sushruta has clearly stated that before surgical operation, the patient should be fed on some favourable food to avoid fainting during the procedure. Not only the preoperative but his postoperative recommendations related to diet and lifestyle are worth to be followed till date.

\section{Surgical Ethics and Consent}

Acharya Sushruta has outlined the ethical aspects and conduct of surgeons. The reference of seeking permission from the king prior to entry to do the medical practice reflects the existence of regulatory body in those times. Reference of obtaining consent prior to the operation is available in 'Ashmari chikitsa' and 'Mood garbha chikitsa prakarana'. Description regarding ethics as available in Sushruta Samhita is a milestone to guide the surgeons of modern times as well.

Principle of Making Incisions and Counter Incisions

In every surgery, making of incision is an important factor that directly affects the outcomes. Well planned incisions heal well in time without complications like delayed healing, wound dehiscence, Keloid formation and incisional hernias. Sushruta dictates that incisions should planned according to site and if so required counter incisions should be given to ensure proper drainage. According to him incision should be made in a single stroke, following the direction of hair and avoiding vital spots, veins, ligaments, joints, bones and arteries.

\section{Description of House for Wounded (Vranitagara)}

Under chapter 19 of Sutra Sthana of Sushruta Samhita, construction of ward for wounded (Vranitagara) has been described with a good architectural design (Vastu Shastra) along with instructions for ward keeping.

\section{Bandaging Techniques (Bandhana Karma)}

There are fourteen types of bandaging techniques described by Acharya Sushruta that are capable of covering almost every part of the body. These are named as Kosha Bandha (for thumb and fingers), Dama Bandha (sling bandage), Swastika Bandha (spica bandage for joints, intermediary region of eye brows and breasts, palms, soles ears), Anuvellita Bandha (spiral bandage for extremities), Muttoli Bandha (winding bandage for cervical region and penis), Mandala Bandha (circular bandage for round parts of body), Sthagika Bandha (stump bandage for dressing of tip of thumb, fingers and penis), Yamaka Bandha (twin bandage for double wounds), Khatva Bandha (four tailed bandage for jaw, temporal region, cheek), Cheena Bandha (eye bandage for eye corners), Vibandha Bandha (multi-tailed bandage for wounds of back, abdomen, chest), Vitana Bandha (cephaline bandage for head), Gophana Bandha (T- bandage for chin, nose, lips, shoulders, pelvis), Panchangi Bandha (five tailed bandage for supraclavicular region). He has also described the technique of tying of bandage (Yantrana). Knot of the tie should never be placed on the wound lest it will cause pain, delayed healing and inconvenience.

\section{Conclusion}

Surgical practice has been considered as an art to protect life and health to an acceptable professional standard. There is no doubt that Legendary Acharya Sushruta and the Indian surgeons of ancient times were well versed with the principles and techniques of surgery. Acharya Sushruta being a great surgeon of his times, has contributed a lot and has laid down the foundation of modern surgery. Due to plentiful reasons, it is unfortunate that Ayurvedic surgery (Shalya Tantra) has almost forgotten and lost its glory. Description in the ancient Ayurvedic literature requires refinement, enhancement, standardization and authentication of Ayurvedic surgical techniques on modern parameters. The 
number of pathologies requiring surgical management is increasing day by day and so are the expenses. It is the need of the hour that Ayurvedic surgeons should be trained and promoted and their services should be utilised in the areas where modern surgeons show reluctance to serve. Advanced researches and technologies are meant for the welfare of all. All the new researches and techniques should be incorporated with zeal and adequate efforts should be made to uplift the standards of Indian Surgery to provide safe, efficient and cost effective surgical care facilities to the suffering humanity.

\section{References}

Dorland's Illustrated Medical Dictionary, 30th ed. W.B. Saunders Company: An Imprint of Elsevier, Philadelphia, USA: 2000.
Priyavrat Sharma. Editor and Translator of Sushruta Samhita, Volume I, 1st edition (reprint). Chaukhambha Visvabharati, Varanasi, 2013.

https://www.woundsource.com: Wound Debridement Options: The 5 Major Methods on April 19 ${ }^{\text {th }}, 2018$.

www.ijrap.net Singh R.K IJRAP 2011, 2(5) 1444-1450: Surgical Procedures in Sushruta Samhita.

Ambikadatta Shastri, translator, Ayurvedatatvasandeepika Hindi commentary on Sushruta Samhita, Part I, $2^{\text {nd }}$ edition (reprint) Chaukhambha Sanskrit Sansthana, Varanasi, 2012.

Priyavrat Sharma. Editor and Translator of Sushruta Samhita, Volume II, Chikitsa Sthana, 1st edition (reprint). Chaukhambha Visvabharati, Varanasi, 2013.

Ambikadatta Shastri, translator, Ayurvedatatvasandeepika Hindi commentary on Sushruta Samhita, Part II, Uttara Tantra, Chapter 58, 59, $7^{\text {th }}$ edition (reprint) Chaukhambha Vishvabharati, Varanasi, 1990. 